See discussions, stats, and author profiles for this publication at: https://www.researchgate.net/publication/328767598

\title{
Facilitating Positive Youth Development through Competitive Youth Sport: Opportunities and Strategies
}

Article $\cdot$ November 2018

DOl: $10.1080 / 08924562.2018 .1516443$

\section{CITATIONS}

2 authors, including:

Fernando Santos

Polytechnic Institute of Porto and Viana do Castelo

18 PUBLICATIONS 18 CITATIONS

SEE PROFILE

Some of the authors of this publication are also working on these related projects:

Project Physical Education and PYD View project

Project Integrating Positive Youth Development in Coach Education View project 


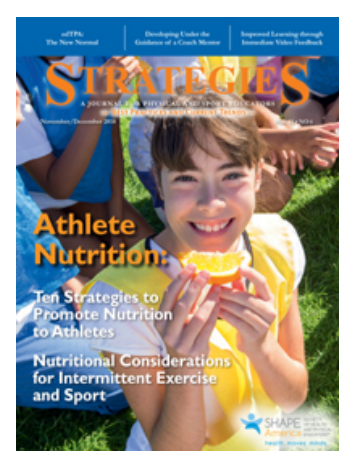

\title{
Strategies
}

A Journal for Physical and Sport Educators

ISSN: 0892-4562 (Print) 2168-3778 (Online) Journal homepage: http://www.tandfonline.com/loi/ustr20

\section{Facilitating Positive Youth Development through Competitive Youth Sport: Opportunities and Strategies}

\author{
Fernando Santos \& Thomas J. Martinek
}

To cite this article: Fernando Santos \& Thomas J. Martinek (2018) Facilitating Positive Youth Development through Competitive Youth Sport: Opportunities and Strategies, Strategies, 31:6, 47-49, DOI: $10.1080 / 08924562.2018 .1516443$

To link to this article: https://doi.org/10.1080/08924562.2018.1516443

曲 Published online: 05 Nov 2018.

Submit your article to this journal ๘

View Crossmark data $[7$ 


\section{Coach's Corner}

\section{Facilitating Positive Youth Development through Competitive Youth Sport:}

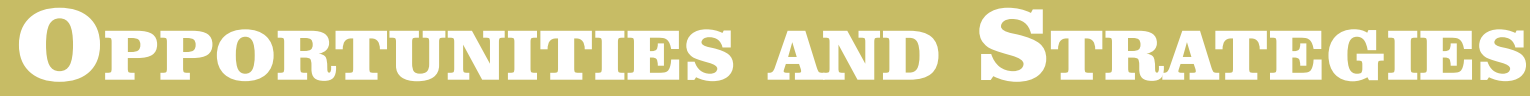

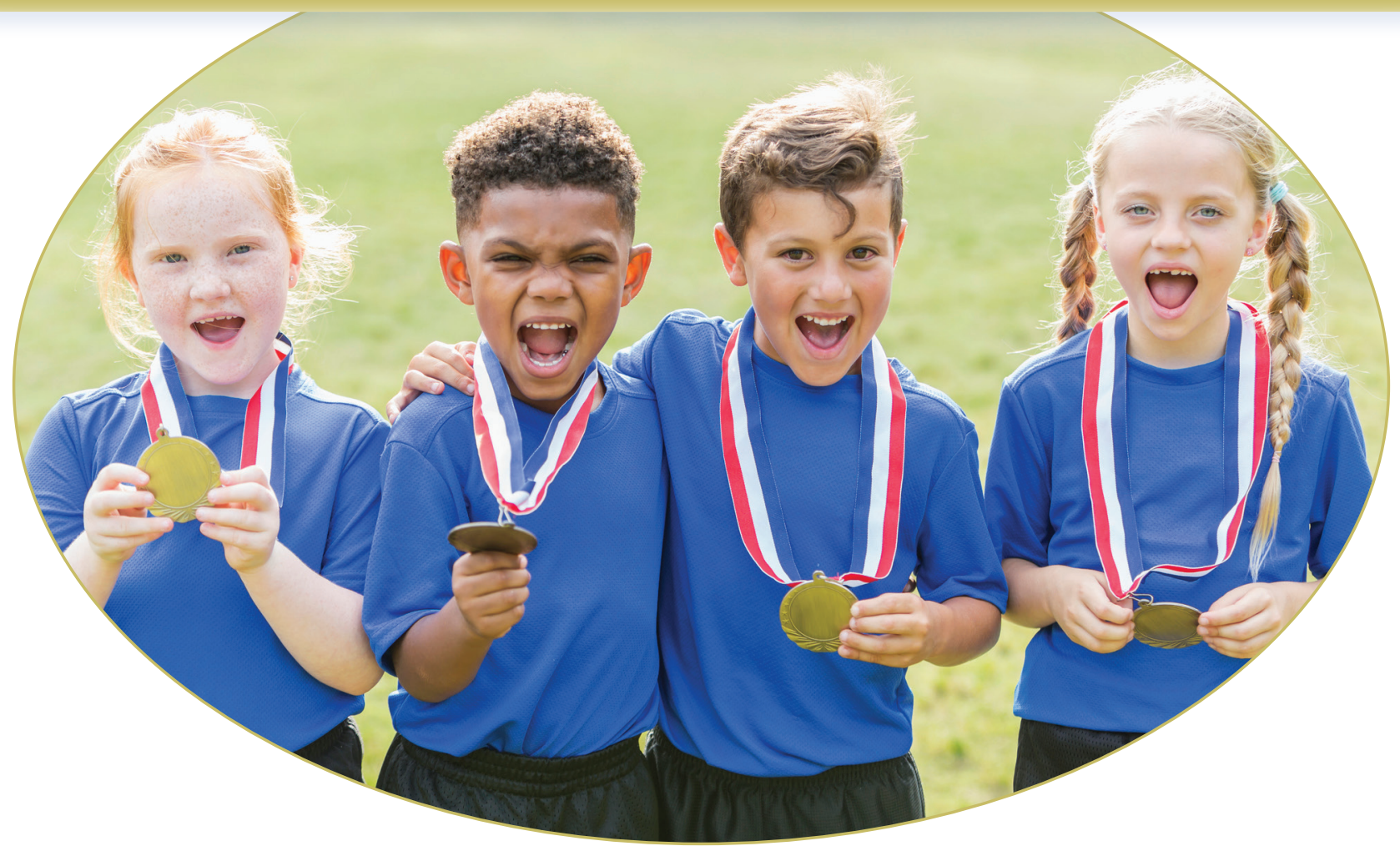

\section{By Fernando Santos and Thomas J. Martinek}

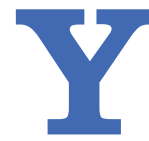

outh sport coaches play a critical role in creating a solid foundation for positive youth development (PYD) and sport skills (Camiré, 2015). Positive youth development is an assetbased approach that implies coaches should intentionally foster the personal and social skills needed in and outside sport (Lerner, Almerigi, Theokas, \& Lerner, 2005). Although many coaches develop ways to include these qualities in their coaching practice, there are several opportunities as well as a set of strategies that may be useful to coaches involved in competitive youth sport. Hence, it is necessary to consider contextspecific strategies that may help coaches who want to promote PYD and sports development through competitive youth sport. Previous articles in this journal (e.g., Mullem \& Brunner, 2013) have suggested the need for helping coaches understand the processes that enhance their coaching practices. 


\section{Opportunities for Positive Youth Development within Competitive Youth Sport}

Competitive youth sport is a fertile platform that can be conducive to PYD outcomes such as perseverance, respect, teamwork and leadership development (Santos, Camiré, \& Campos, 2016). As such, opportunities for PYD present themselves constantly.

First, the performance focus present in competitive youth sport provides meaning to the experiences as well as reflections and life lessons. Winning, losing and striving for team objectives, to name a few learning opportunities, may enable PYD during coachable moments (Côté, Turnnidge, \& Evans, 2014). To use the potential of competitive youth sport, coaches should 1) intentionally use these opportunities to foster PYD, 2) highlight how these personal and social skills might be used outside of sport, and 3) provide support as athletes internalize and apply a particular skill. Additionally, PYD develops personal and social skills, could help athletes learn sport skills, and could influence game performance (Anderson, 1999). If athletes are able to define sound goals, lead others, develop self-control, and persevere, there is an increased likelihood that they will learn a vast array of sport skills. Finally, given that coaches spend significant amounts of time with athletes within competitive youth sport, it is possible to promote PYD and attain more outcomes in comparison with less demanding sport contexts such as recreational sports (Strachan, Côté, \& Deakin, 2011).

\section{Positive Youth Development Strategies for Competitive Youth Sport}

This section presents four specific PYD strategies that focus on the nature of the competitive youth sport context. First, coaches involved in competitive youth sport have the dual role of facilitating performance outcomes and facilitating PYD outcomes (Gilbert \& Trudel, 2006). This role is time-consuming and demanding (Coakley, 2016), as coaches must define a specific set of personal and social skills that align with athletes' characteristics during specific competitive periods of the season (e.g., preseason, off-season). Coaches could define these personal and social skills while focusing on the sport skills that are being developed. For example, if coaches aim to develop accuracy in free kicks, it might be valuable to define goal setting and perseverance as important skills on which to work. This integration process makes PYD a feasible endeavor and may contribute to the relationship between sport development and personal and social skill development.

Second, it is necessary to explicitly state these skills as PYD objectives so athletes can assess their own performance. The language used should consider the target age group to help athletes understand the meaning of leadership and what leadership means for them in a practice or game. It is easier to define a small attainable PYD objective with a certain number of players and then expand those objectives to the whole team.
Cultural and social forces (e.g., past experiences with former coaches, personal objectives) might in some cases lead athletes to not acknowledge the importance of these objectives.

Third, before changing a coaching practice entirely, coaches need to reflect on the possibility of using potential coachable moments that already exist in their coaching practice, team routines and strategies. If a coach assigns a warm-up leader in a nondeliberate manner and without a PYD focus, it would be beneficial to do it more deliberately and consistently over time. Furthermore, after shifting from a nondeliberate to a deliberate approach, it is important to create new PYD strategies and integrate them progressively based on certain criteria:

- Do they align with PYD objectives?

- Do they lead athletes to discover for themselves the importance of a specific skill during drills (e.g., a drill that requires teamwork and athletes are failing to do it)?

- Is their value applied in coaching practice?

- Do they promote reflection about institutionalized competitive youth sport and provide a different outlook (e.g., the winning team stays in a drill vs. the losing team stays because there is a clearer need for improving)?

- Do they help coaches to reflect and create their own PYD strategies (Pierce, Gould, \& Camiré, 2017)?

Fourth, coaches should develop a sense of consistency between expectations and PYD objectives in games and practices, which means posing specific questions like: What do I accept for my team while losing and winning a game? What is the value given to a PYD objective in the first game and in the finals?

To capitalize on the opportunities that exist in competitive youth sport, coaches could develop a PYD mandate consistent with the nature of this context and truly integrate the approach in their coaching practice instead of drifting away from the principles behind competitive youth sport (Vella, Oades, \& Crowe, 2011).

\section{References}

Anderson, D. (1999). Life skill intervention and elite athletic performance. Footscray, Victoria, Australia: Victoria University of Technology.

Camiré, M. (2015). Reconciling competition and positive youth development in sport. STAPS, 109, 25-39.

Coakley, J. (2016). Positive youth development through sport: Myths, beliefs, and realities. In N. Holt (Ed.), Positive youth development through sport (2nd ed., pp. 21-33). New York, NY: Routledge.

Côté, J., Turnnidge, J., \& Evans, B. (2014). The dynamic process of development through sport. Kinesiologia Slovenica, 20(3), 14-26.

Gilbert, W., \& Trudel, P. (2006). The coach as a reflective practitioner. In R. Jones (Ed.), The sports coach as educator: Re-conceptualising sports coaching (pp. 113-129). New York, NY: Routledge.

Lerner, R., Almerigi, J., Theokas, C., \& Lerner, J. (2005). Positive youth development: A view of the issues. The Journal of Early Adolescence, 25, 10-16.

Mullem, P., \& Brunner, D. (2013). Developing a successful coaching philosophy: A step-by-step approach. Strategies, 26(3), 29-34. 
Pierce, S., Gould, D., \& Camiré, M. (2017). Definition and model of life skills transfer. International Review of Sport E Exercise Psychology, 10, 186-211.

Santos, F., Camiré, M., \& Campos, H. (2016). Youth sport coaches' role in facilitating positive youth development in Portuguese field hockey. International Journal of Sport and Exercise Psychology, 16(3), 221-234.

Strachan, L., Côté, J., \& Deakin, J. (2011). A new view: Exploring positive youth development in elite sport contexts. Qualitative Research in Sport, Exercise and Health, 3, 9-32.

Vella, S., Oades, L., \& Crowe, T. (2011). The role of the coach in facilitating positive youth development: Moving from theory to practice. Journal of Applied Sport Psychology, 23, 33-48.

Fernando Santos (fernando.sfsantos@hotmail.com) is an associate professor in the School of Higher Education at the Polytechnic Institute of Porto in Porto, Portugal; and Thomas J. Martinek is a professor in the Department of Kinesiology at the University of North Carolina in Greensboro, NC.

\section{Submissions Welcome!}

Readers are encouraged to send "Coach's Corner" submissions to Strategies Managing Editor Laura Strecker at Istrecker@shapeamerica.org.

The purpose of the Coach's Corner column is to feature short articles about one specific coaching lesson that readers can immediately implement with their team. Articles should contain a brief introduction, followed by quick-hitting information such as bullet points or lists. Submissions should not exceed $1,000-1,500$ words (or roughly four typed, doublespaced pages).

\section{Mark Your Calendar}

The SHAPE America National Convention \& Expo is coming to these locations.

Make plans to learn and network at the nation's premier professional development event for school-based health and physical educators.

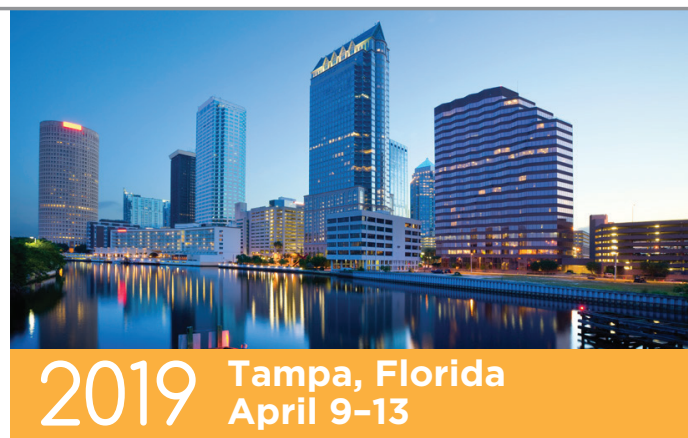

SHAPE AnO AND PHYSICAL health. moves. minds.

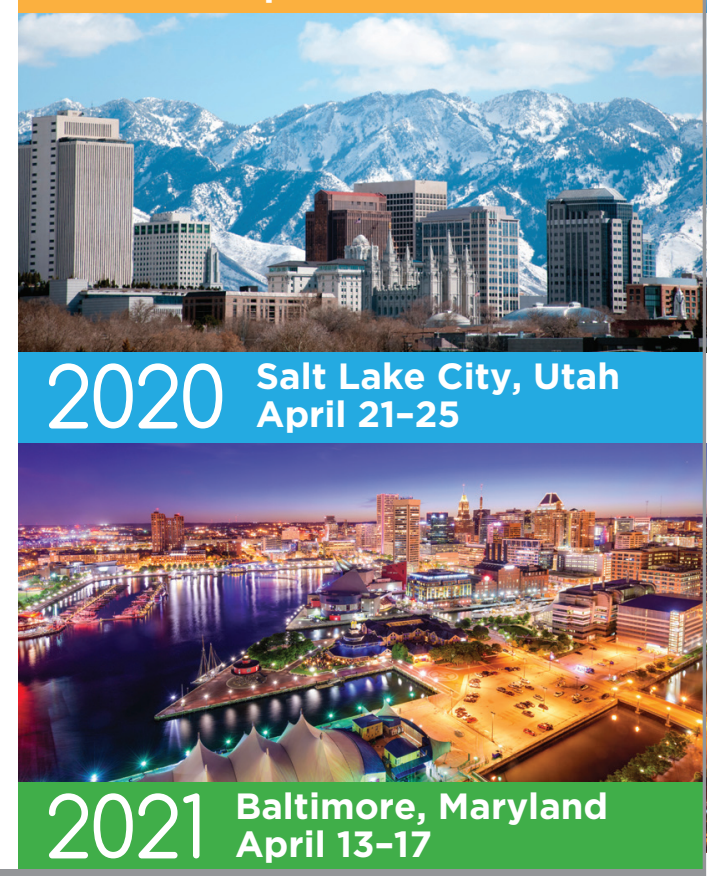

\section{Visit shapeamerica.org/convention}

